\begin{tabular}{|c|c|}
\hline in & $\begin{array}{l}\text { International Journal of Trend in Scientific } \\
\text { Research and Development (IJTSRD) }\end{array}$ \\
\hline 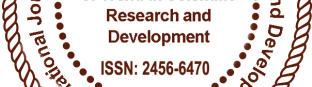 & International Open Access Journal \\
\hline 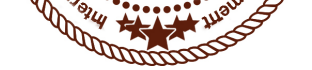 & ISSN No: 2456 - 6470 | www.ijtsrd.com | Volume - 2 | Issue - 5 \\
\hline
\end{tabular}

\title{
Momentous of Corporate Governance in the Capital Market
}

\author{
Mayank Goyal, Dipanshu Mishra
}

B.A., L.L.B. - VI Sem., Student

S. S. Jain Subodh Law College, Rajasthan University, Jaipur, Rajasthan, India

\section{ABSTRACT}

There has been amplify in attention in the Corporate Governance practices in modern era since 2001, particularly due to number of high profile financial scandals of large corporation, most of which complicated in accounting fraud such as Satyam Computers, Enron Corporation etc.. After the number of corporate financial scandal in the early part of the decade, it raised the pressure on investors on companies to strengthen corporate governance arrangement by unscrambling the roles of chairman and CEO.

The wide-reaching gesticulate of laissez fair or isolationism, privatization, take over, pension fund reforms and the enlargement of private savings are the reasons why the corporate governance becomes so high up today.

Investors from developed countries are challenging those Indian companies to chase international best practices with an emphasis on corporate governance. A McKinsey survey conducted in 2002, found that investors were willing to pay a premium for a well governed company (Barton et al. 2006). Among all other forces, four major energetic forces can be acknowledged for the materialization of corporate governance in India. These include Globalization, Privatization, unprincipled business practices and sanctuary scams.

The corporate governance disturbed with many stakeholders and goals for which the corporation is formed. The valuable and ethical governance practice of the corporate is to facilitate the nation to cultivate economically. Government of any countries expects the growth, employment, wealth and satisfaction through valuable governance. Furthermore, it should raise the living standard of the society and increase in adhesiveness of society.

Keywords: Corporate sector, Legislation, stakeholder, Capital Market, Security Exchange Board of India

\section{CONCEPT OF CORPORATE GOVERNANCE}

The prepositions of good governance are as old as good conduct, which needs no official definition. However, in attributing to corporate world, it has been expressed by various persons, some of whom is elucidated below just in order to conciliate that the basic details and essence of the term are not removed.

The Kumar Mangalam Birla Committee constituted by SEBI has observed that "Strong corporate governance is imperative to recover and active capital markets and is a significant mechanism of investor security. It is the blood that fills the veins of crystalline corporate admission and high quality accounting rules. It is the tissues that actions an applicable and attainable financial reporting structure". In its present form, Clause $49^{1}$, called 'Corporate Governance', contains eight sections dealing with the Board of Directors, Audit Committee, Remuneration of Directors, Board Procedure, Management, Shareholders, Report on

\footnotetext{
${ }^{1}$ Clause 49 of the Listing Agreement contains the guidelines on Corporate Governance for all Listed Companies and applies to all Listed Companies (or those that are seeking listing), except for very small companies (that is, those that have a paid-up capital of less than Rs. 30 million and a net worth of less than Rs. 250 million throughout their history). While several requirements of Clause 49 are mandatory in nature, there are certain requirements (such as the setting up of a remuneration committee, training of board members and whistleblower policy) that are merely recommendatory in nature.
} 
Corporate Governance, and Compliance, respectively. Firms that do not comply with Clause 49 can be delisted and charged with financial penalties.

N.R. Narayana Murthy Committee ${ }^{2}$ on Corporate Governance constituted by SEBI has described "Corporate Governance is the approval by management, of the inalienable rights of shareholders as the true governance of the corporation and of their own role as trustees on account of the shareholders.

Law can only provide a minimum code of conduct for proper regulation of human being or company ${ }^{3}$. Law is made not to stop any act but to assure that if you do that act, you will face such residues i.e. good for good and bad for bad. Thus, in the same aspect, role of law in corporate governance is to additive and not to substitute. It cannot be only way to govern corporate governance but instead it provides a minimum code of conduct for good corporate governance. Law provides certain ethics to govern one and all so as to have maximum achievement and minimum abrasion. It plays a completely and correlatively role. Role of law in corporate governance is in Companies Act which ensures certain restrictions on Directors so that there is no adulteration of documents, there is no extreme of power, so that it imposes duty not to make secret profit and make good losses due to breach of duty, negligence, etc, duty to act in the best interest of the company etc.

\section{HISTORICAL BACKGROUND IN INDIA REGARDING IN MATTERS OF CORPORATE GOVERNANCE}

The concept of good governance is very old in India dating back to third century B.C. where Chanakya (Kautliya) ${ }^{4}$ elaborated fourfold duties of a king viz. Raksha, Vriddhi, Palana and Yogakshema. ${ }^{5}$ Substituting the king of the State with the Company $\mathrm{CEO}$ or Board of Directors the principles of Corporate Governance refers to protecting shareholders wealth (Raksha), enhancing the wealth by proper utilization of assets (Vriddhi), maintenance of wealth through

\footnotetext{
${ }^{2}$ Securities and Exchange Board of India, Report of the SEBI Committee on Corporate Governance (February 2003), Available at: http://www.sebi.gov.in/commreport/corpgov.pdf. (Narayana Murthy Committee Report)[10 July 2018; 10:30 $\mathrm{pm}]$.

${ }^{3}$ Report of Company Affairs Committee of the "Confederation of the British Industry", Page 71 Company Affairs Committee.

${ }^{4}$ Arthashastra, Book I, Chapter XIX.

${ }^{5}$ R Shamastry, "Kautilya's Arthashastra".
}

profitable ventures (Palana) and above all safeguarding the interests of the shareholders (Yogakshema or safeguard) ${ }^{6}$.

Corporate Governance was not in agenda of Indian Companies until early 1990s and no one would find much attributing to this subject in book of law till then. In India, infirmity in the system such as inadmissible stock market practices, boards of directors without accessible fiduciary answerabilities, poor disclosure practices, lack of transparency and chronic capitalism were all crying for restore and improved governance.

The fiscal crisis of 1991 and resulting need to approach the IMF convinced the Government to adopt disciplinary activities for economic stabilization through liberalization. The strength collected even thoroughly slowly once the economy was pushed open and the liberalization process got initiated in early 1990 s.

As a part of liberalization process, in 1999 the Government amended the Companies Act, 1956. Further amendments have followed subsequently in the year 2000,2002 and 2003. A variety of methods have been adopted including the powering of certain shareholder rights (e.g. postal balloting on key issues), the accrediting of SEBI (e.g. to prosecute the defaulting companies, increased sanctions for directors who do not accomplish their accountability, limits on the number of directorships, changes in reporting and the requirement that a 'small shareholders nominee' be selected on the Board of companies with a paid up capital of Rs. 5 crore or more).

\section{J. J. IRANI COMMITTEE REPORT;}

The Companies Act 1956 was enacted on the advocacy of the Bhaba Committee established in 1950 with the aim to add to the existing corporate laws and to bring a new foundation for corporate motion in independent India. With enactment of this legislation in 1956 the Companies Act 1913 was abrogated.

After an unwilling beginning in 1980, India took up its economic improve business in 1990s and a need was felt for an all embracing review of the Companies Act 1956. Ineffective undertakings were made in 1993 and 1997 to displace the present Act with a new law.

\footnotetext{
${ }^{6}$ Complete Chanakya Neeti, Manoj Publication, New Delhi.
} 
The essence for integrating this Act was explored from time to time as the corporate sector advance in pace with the Indian economy and as many as 24 amendments have taken place since 1956. The major amendments to the Act were made through Companies (Amendment) Act 1998 after considering the recommendations of Sachar Committee followed by another amendments in 1999, 2000, 2002 and finally in 2003 through the Companies (Amendments) Bill 2003 following to the report of R.D. Joshi Committee ${ }^{7}$.

In the current national and international context the essence for explaining corporate laws has long been felt by the government and corporate sector so as to make it agreeable to clear clarification or apprehension and provide a scheme that would speedup economic growth.

The Government therefore took a fresh ambition in this regard and created a committee in December 2004 under the chairmanship of Dr. J.J. Irani with the task of guiding the government on the advanced revisions to the Companies Act 1956.The recommendations of the Committee submitted in May 2005 mainly relate to management and board governance, related party transactions, minority interest, investors education and protection, access to capital, accounts and audit, mergers and consolidations, offences and penalties, reconstitution or reestablishment and liquidation, etc ${ }^{8}$.

\section{SIGNIFICANT OF CORPORATE GOVERNANCE IN THE CAPITAL MARKET}

Good corporate governance standards are essential for the integrity of corporations, financial institutions and markets and have a bearing on the growth and stability of the economy. Over the past decade, India has made significant strides in the areas of corporate governance reforms, which have improved public trust in the market.

These reforms have been well received by the investors, including the foreign institutional investors (FIIs). A compelling evidence of the improving standards comes from the growing interest of FIIs in the Indian market; gross FII portfolio investment has risen from US \$ 2.7 billion in FY 1996 to US \$ 166.2 billion in FY 2013.

\footnotetext{
${ }^{7}$ Irani Jamshed J., Report of the Expert Committee to Advise the Government on the New Company Law (2005).

${ }^{8}$ J.J. Irani Report on Company law, 2005.
}

Governance reforms and globalization of the capital markets have been mutually reinforcing. While continuing governance reforms have led to rising foreign investment, globalization of the capital markets has provided an impetus to the Corporate Governance practices in the following manner.

An important side effect of internationalization of Indian capital markets was a drive toward a more stringent corporate governance regime by the Indian industry itself. To market their securities to foreign investors, Indian companies making public offerings in India were persuaded to comply with corporate governance norms that investors in the developed world were familiar with. Further, Indian companies listing abroad to raise capital were subject to stiff corporate governance requirements applicable to listing on those Exchanges.

They also adhered to the norms and practices of corporate governance applicable to markets where they listed their securities. It must however be recognized that such practices have remained largely confined to only some large companies and have not percolated to majority of Indian companies.

\section{SEBI CONSULTATIVE PAPER ON CORPORATE GOVERNANCE}

In early 2012, SEBI released a consultative paper on "Review of Corporate Governance Norms in India". To improve the governance standards of companies in India, the report had provided a broad framework in the form of overarching principles of corporate governance, and proposals. The objective of the concept paper was to attract a wider debate on the governance requirements for the listed companies so as to adopt better global practices.

An attempt was made to ensure that the additional cost of compliance with the proposals did not outweigh the benefits of listing, while at the same time the need to boost the confidence of the investors on the capital market was recognized.

\section{REGULATORY FRAMEWORK FOR CORPORATE GOVERNANCE IN INDIA}

As a part of the action or advance of economic liberalization in India, and the procedure toward further evolution or expansion of India's capital markets, the Central Government well settled regulatory control over the stock markets through the design of the SEBI. Originally well settled as an 
advisory body in 1988, SEBI was admitted the authority to regulate the securities market under the Securities and Exchange Board of India Act of 1992 (SEBI Act $)^{9}$.

Public listed companies in India are governed by a multiple regulatory structure. The Companies Act is supervised by the Ministry of Corporate Affairs (MCA) and is presently enforced by the Company Law Board (CLB). That is, the MCA, SEBI, and the stock exchanges share jurisdiction over listed companies, with the MCA being the primary government body owed with supervising the Companies Act of 1956, while SEBI has offered as the securities market regulator since 1992.SEBI serves as a market-oriented autonomous body to regulate the securities market alike to the role of the Securities and Exchange Commission (SEC) in the United States. The stated ambition of the agency is to protect the interests of investors in securities and to advocate the development of, and to direct, the securities market.

The domain of SEBI's statutory authority has also been the subject of comprehensive debate and some authors ${ }^{10}$ have lifted doubts as to whether SEBI can make regulations in respect of matters that fall within the jurisdiction of the Department of Company Affairs.

SEBI's authority for carrying out its regulatory accountabilities has not always been bright and when Indian financial markets accomplished colossal share price equipments frauds in the early 1990s, it was found that SEBI did not have sufficient statutory power to carry out a full investigation of the frauds. ${ }^{11}$

\footnotetext{
9 The SEBI Act provides for the establishment of a Board to protect the interests of investors in securities and to promote the development of, and to regulate, the securities market in India.

${ }^{10}$ Pandey, T.N SEBI for a view that many of SEBI's actions have been beyond their intended jurisdiction. See also Afsharipour, Afra: Corporate Governance Convergence: Lessons from the Indian Experience (2009), for a comprehensive coverage on the issue of the conflicting jurisdiction between SEBI and the Ministry of Corporate Affairs.
}

11 The Securities and Exchange Board of India (Amendment) Act, 2002, amended the Securities and Exchanges Board of India Act, 1992 and enlarged its Board of Directors, besides conferring on SEBI the powers of search and seizure, with the approval of courts, and enhancing the fine for a better and hassle-free regulation of the capital market.
Accordingly, the SEBI Act was amended in order to allocate it sufficient powers with respect to inspection, investigation, and enforcement, in line with the powers allocated to the SEC in the United States.

Distinguishing that a problem arising from an overlay of jurisdictions between the SEBI and MCA does exist, the Standing Committee, in its final report, has endorsed that while providing for minimum benchmarks, the Companies Bill should allow sectored regulators like SEBI to discharge their designated jurisdiction through a more detailed regulatory dynasty, to be decided by them according to circumstances ${ }^{12}$. Attributing to a similar case of jurisdictional overlay between the RBI and the MCA, the Committee has recommended that it needs to be accordingly enunciated in the Bill that the Companies Act will prevail only if the Special Act is silent on any manner.

Further the Committee recommended that if both are silent, essential provisions can be included in the Special Act itself and that the status quo in this regard may, therefore, be maintained and the same may be pleasantly clarified in the Bill. This, in the Committee's view, would assure that there is no jurisdictional overlay or conflict in the governing statute or rules framed there under.

\section{COMPANIES BILL, 2011 AND ITS IMPACT ON CORPORATE GOVERNANCE IN INDIA}

The basis of the umbrella revision in the Companies Act, 1956 was laid in 2004 when the Government formed the Irani Committee ${ }^{13}$ to conduct an extensive review of the Act. The Government of India has placed before the Parliament a new Companies Bill, $2011^{14}$ that incorporates several important provisions for bettering corporate governance in Indian companies which, having gone through an expensive consultation process, is expected to be approved in the 2012 Budget session.

The new Companies Bill, 2011 introduces formational and fundamental changes in the way companies would be governed in India and incorporates various lessons that have been learnt from the corporate scams

\footnotetext{
${ }^{12}$ Report to the Indian Parliament, "The Standing Committee of the Parliament (Standing Committee)" Bill submitted in August 2010 .
${ }^{13}$ Irani Jamshed J., Report of the Expert Committee to Advise the Government on the New Company Law (2005).
${ }^{14}$ The Companies Bill, 2011.


of the recent years that displayed the role and importance of good governance in organizations.

Significant corporate governance redeems, primarily focused at battering the board delinquency process, have been proposed in the new Companies Bill; for instance it has proposed, for the first time in Company Law, the concept of an Independent Director and all listed companies are required to appoint independent directors with at least one-third of the Board of such companies comprising of independent directors.

The Companies Bill, 2011 takes the concept of board independence to another level altogether as it allots two sections ${ }^{15}$ to deal with Independent Directors. The definition of an Independent Director has been appreciably binding and the definition now defines positive characters of independence and also requires every Independent Director to announce that he or she meets the basis of independence.

In order to establish that Independent Directors maintain their independence and do not become too familiar with the management and promoters, minimum tenure requirements have been recommended. The initial term for an independent director is for five years, following which further appointment of the director would require a special resolution of the shareholders.

The new guidelines which set out the role, functions and duties of Independent Directors and their appointment, resignation and evaluation advance greater clarity in their role; however, in certain places they are authoritative in nature and could end up making the role of Independent Directors quite exigent.

In the background of the current provisions in the Companies Act, 1956 which do not provide any clear limitation of liability and have left it to be interpreted by Courts $^{16}$, it is helpful to provide a limitation of

\footnotetext{
15 Section 149 and 150 of the Companies Bill, 2011 Parliament of India (Bill No. 121 of 2011).

16 The 2009 experience of Nimesh Kampani, one of India's leading investment bankers is very relevant to see how unstable the position of independent directors is under the Companies Act, 1956. Kampani served as an independent director on the board of Nagarjuna Finance from 1998 to 1999.21 The promoters and executives of Nagarjuna were later charged under the Andhra Pradesh Protection of Creditors Act for failing to repay depositors nearly Rs. 100 crore during 20012002. Surprisingly, in addition to charging and arresting the
}

liability clause. The new Bill also requires that all resolutions in a meeting convened with a shorter notice should be ratified by at least one independent director which gives them an element of veto power. Various other clauses such as those on directors' responsibility statements, statement of social responsibilities, and the directors' responsibilities over financial controls, fraud, etc, will create a more transparent system through better disclosures.

A major proposal in the new Bill is that any undue gain made by a director by abusing his position will be disgorged and returned to the company together with monetary fines. A significant first, in the proposals under the new Companies Bill, is the provision that has been made for class action suits.

The Companies Bill, 2011 seeks to provide clarity on the respective roles of SEBI and the MCA and demarcate their roles - while the issue and transfer of securities and non-payment of dividend by listed companies or those companies which intend to get their securities listed shall be administered by the SEBI all other cases are proposed to be administered by the Central Government.

\section{CORPORATE SOCIAL RESPONSIBILITY AND SMALL AND MEDIUM ENTERPRISES}

What are SMEs? Small and medium enterprises (SMEs) significantly grant towards India's economic growth. These serve freely and also as ancillary to bigger units and help generate employment and industrialise the countryside and backward regions of India. They employ nearly $40 \%$ of India's workforce and subscribe around $45 \%$ to India's manufacturing output. What do they do? The business activities of SMEs are performed in almost to the locals. This enables them to be knowledge of community needs, manage expectations and expand CSR programmes appropriately.

Now that the CSR clause in the Companies Act, 2013 covers companies that have a net profit of five crore INR and above, it is expected that while microenterprises will not qualify, many small and medium enterprises (SMEs) will. SMEs are being treated

founding promoter and another affiliated director, the Government also charged Kampani, who had left the board prior to any of the allegations surfacing. Kampani managed to avoid arrest and jail time by remaining in Dubai for nine months until a ruling by the Supreme Court of India in October 2009 stayed the proceedings against him. 
separately in this article because of their clear-cut features. The CSR activities of these enterprises are come for the personal interests of promoters who hold a significant financial stake in the business.

They tend to be in clusters and engaged in similar business activities. While the quantum of revenue available for CSR with individual SMEs is expected to be small, all eligible companies in a specific geographical cluster, who single handed as well as collectively impact the same community, can pool their resources to create a sizeable CSR fund ${ }^{17}$.

\section{HOW CAN SMES CONTRIBUTE TO CSR INITIATIVES?}

This section, deals with the option of undertaking common CSR activities by Small and medium enterprises. This amalgamation can also be used by other companies to maximise the collision of their CSR initiatives while diminishing the operational costs for fund management.

Why collaborate for CSR resourceful? CSR is for all companies. SMEs in India have participated in CSR activities but these efforts have not been optimally delivered. One possible reason can be the fact that CSR activities build upon the profits of an SME and any inconstancy in profits can adversely affect their capability to continue their contribution for CSR. Another reason can be the limited human resources available to SMEs which may also result in the lack of a professional approach. SMEs tend to focus on shortterm activities that involve lesser operational costs. A survey conducted by UNIDO $^{18}$ in 2008 on five SME clusters in India, found that $31 \%$ to $79 \%$ of the SMEs in these clusters, preferred charity donations rather than long-term programmes for local communities. With the introduction of the new Companies Act, 2013, the SME's approach to CSR has to be modified while keeping operational costs low. One viable alternative is to pool resources with other SMEs in the chunk and create joint CSR programmes managed by a single entity. This collusion can be formed within the units in a bunch as they interact with the same communities and have already established

\footnotetext{
${ }^{17} \mathrm{http} / / /$ www.academia.edu/4278012/Promotion_of_Small_and_ Medium_Scale_Enterprises_and_their_Contribution_to_the_Eco nomic_Growth_of_Nigeria (Apr. 2, 2018, 10:20 PM ) 18 United Nations Industrial Development Organization.
}

associations that cater to the business needs of the units. $^{19}$

\section{COLLABORATION HAS THE FOLLOWING ADVANTAGES:-}

Undertake long-term projects: A major barrier in developing long term projects is the uncertainty in the CSR budget. This is dependent on the financial performance of the company. A flutter performance implies that the CSR budget allocations can be uncertain and can jeopardise a programme started earlier. Pooling resources addresses this issue to a certain amount as the other partners can raise their share in case there is deviation in allocation from a certain sector of the cluster. The long term programmes also have greater effect than the shortterm projects. Communities are more and more realising the importance of the support offered by these programmes in making their lives better. Longterm programmes also lead to better community relations and this certifies avoiding situations of community anxiety that harm business activities.

Learning from experiences: A common entity with multiple participants from the collection will help assess community needs, undertake related programmes based on past experiences and address a greater number of community issues. Combination among the SMEs in a cluster also provides an opportunity to manage social and environmental issues and respond better to the pressure from buyers, who are trying to form an ethical supply chains and gain recognition from the international community. Collaborations can also be forged amongst larger companies, possibly through industry associations, to enable them to address common issues plaguing a geographical region or an industry. ${ }^{20}$

\section{WHY IS THE CSR CLAUSE OF THE NEW COMPANIES ACT, 2013 SO CRITICAL FOR SMES?}

By requiring companies, with a minimum net profit of 5 crore INR, to spend on CSR activities, the Companies Act, 2013 is likely to bring in many SMEs into the CSR fold. This will usher in a fresh set of challenges to a sector that is increasingly being asked

\footnotetext{
${ }^{19}$ Available at; https://blog.ipleaders.in/corporate-socialresponsibility-smes/ (Apr. 02, 2018, 11:05 AM).

${ }^{20}$ Available at; $\quad$ http://www.businessstandard.com/article/sme/smes-to-get-professional-help-oncorporate-social-responsibility-108060501090_1.html (Apr. 03, 2018, 04:00 PM).
} 
by its B2B customers to comply with environmental and social standards, while remaining competitive in terms of price and quality. Thus, SMEs will have to quickly learn to be compliant with these diverse set of requirements and it is hoped that this handbook will facilitate their ability to comply with the CSR clause of the Companies Act, 2013.

\section{CONCLUSION}

We may conclude that the Corporate Governance in a narrow and broad definition. In the narrow sense, corporate governance associates a set of consanguinity amongst the company's management, its board of directors, its shareholders, its auditors and other stakeholders. These consanguinities, which associate various code and encouragements, provide the anatomy through which the aims of the company are set, and the means of acquiring these objectives as well as monitoring performance are strong- minded.

In a broader sense, however, good corporate governance the ambits to which companies are run in an accessible and transparent manner is important for inclusive market confidence, the capabilities of capital allocation, the growth and development of countries' industrial bases, and conclusively the nations' inclusive wealth and welfare. It is significant to note that in both the narrow as well as in the broad definitions, the concepts of acknowledgement and fairness employ center-stage. In the first ground, they create faith at the firm level among the suppliers of finance. In the second ground, they create inclusive confidence at the accumulate economy level. In both cases, they result in efficient allocation of capital.

\section{REFERENCES:}

1. Cragg, Wesley, Ethics Codes, Corporations and the Challenge of Globalization, 2005. Goel, Ran, Guide to Instruments of Corporate Responsibility: An overview of 16 tools for labour fund trustees, 2005.

2. Bohman, Anna and Minter, Graham, International Initiatives to Promote Responsible Business: Confusion or Coherence? International Business leaders Forum, 2007.

3. The 181 member states of the ILO, and their workers' and employers' organizations founded in 1919.

4. OECD, Environment and the OECD Guidelines for Multinational Enterprises: Corporate Tools and Approaches, OECD, 2005

5. OECD, Policies for Promoting Responsible Business Conduct, in Policy Framework for Investment: A Review of Good Practices, 2006

6. OECD, Chapter 7: Policies for Promoting Responsible Business Conduct, in Policy Framework for Investment, 2006 